\title{
Ababa: Pathfinder International/Ethiopia Determinants of Tax Compliance Behavior in Category "C" Business Income Tax Payers in Gozamen District, East Gojjam Zone, Ethiopia
}

\author{
Yeshiwas Ewinetu \\ Debre Markos University, Debre Markos ,Ethiopia
}

\begin{abstract}
The main purpose of this paper is to investigate determinants of tax compliance behavior in category "C" business income tax payers in Gozamen woreda / district/. To this end, the researcher follows quantitative research approach and descriptive research design. The researcher used cross sectional primary data collected from 318 category $\mathrm{C}$ business income tax payers selected with simple random sampling techniques. The study employed both descriptive statistics, and inferential statistics methods of data analysis. The descriptive statistics was summarized using average, minimum, maximum, standard deviation, percentage and frequency, and it was also presented in the form of multipurpose table, bar graph and histo-graph inferential statistics Binary Logit model was applied. The study finding reveled that tax compliance behavior is negatively affected by the influence of referent group and experience on business activity at 1 percent level of significance but positively influenced by legal sanction and penalty which is statistically significant at 1 percent level of significance. Based on the above findings, the researcher recommends that, to improve the probability of tax compliance behavior of category "C" business income tax payers, Gozamen Woreda Revenue office should create awareness in reducing the influence of referent group on tax payer, create awareness of experienced business man to rise tax compliance behavior and finally after awareness creation, impose legal sanction and penalty or enforcing tax laws and regulation to rise tax complaince behaviour of category $\mathrm{C}$ business income tax payers in the study area . Keywords:-Determinants, Tax compliance behavior, Gozamen district, Binary logit model.
\end{abstract}

DOI: $10.7176 / \mathrm{RJFA} / 10-17-02$

Publication date:September $30^{\text {th }} 2019$

\section{Introduction}

Tax is a compulsory contribution collected by the government to finance spending in performing government functions of defending a country, infrastructure development for economic activities and, peace keeping (Bhatia, H.L.1976). The amount of revenue collected alone could not explain the best tax administration. A poor quality of tax administration may also collect large amount of revenue from easy to tax sectors such as wage earners, while unable to enforce taxes on business enterprises and professionals. Hence, measuring the effectiveness of the tax administration by the size of tax collected is unsophisticated judgment. Considering the size of the compliance gap is rather a much stronger criterion to the effectiveness of tax administration (FIRA, 2000). In many under developed countries like Ethiopia, the low revenue yield of taxation can only be attributed to the fact that the tax provisions are not properly enforced, either on account of the inability of the administration to cope with them, or on account of straightforward corruption. But factors on the other side of the system get little attention, i.e. minor attention is given to the cultural background of tax payers, their awareness level, compliance behavior and its determinants when designing a given tax system(ibid ,2000).

It is argued that improved tax compliance boosts the revenues available for supporting public services without increasing the current tax burden on compliant tax payers the taxpayers today are demanding more assistance and fair treatment from the tax authorities to promote equitable distribution of income (Lemessa , 2007).

For voluntary system to work successfully, the people must be confident that the taxes are levied fairly and that everyone pays his share. If the feeling becomes widespread that the tax system is a collection of loopholes and evasions, if people see their equally prosperous neighbors paying substantially less or enjoying tax free expense account living, taxpayer morale declines. Once this attitude prevailed in the public it is difficult to rectify it and costs the authorities a huge compliance and collection costs.

Raising more domestic revenue is a priority for most sub-Saharan African countries (Drummondet $a l, .2012)$.

Mobilizing revenue is a way for governments' to create fiscal space, provide essential public services, and reduce foreign aid and single resource dependence. However, the domestic tax bases in most African countries are undermined by widespread tax avoidance an evasion (IMF 2011). Although taxpayer non - compliance is a continual and growing global problem (McKerchar and Evans, 2009). Many indications suggest that developing countries, many of them in Sub - Saharan Africa, are the hardest hit (Cobham 2005;Fuest and Riedel 2009).

Dealing with the problem of tax evasion requires at least some understanding of the factors underlying the 
individual taxpayer's decision whether to pay or evade taxes. However, little is known about tax compliance behavior in developing countries (Andreoni et al., 1998; D’Arcy 2011; Fjeldstad and Semboja,2001).

And hence, this study aims at identifying factors that affect the tax payer's voluntary compliance i.e. what factors motivate taxpayers to comply with the tax system or what factors influence tax payers not to comply with tax system. The output of this study helps the tax authority to incorporate measures that address these pitfalls while designing a tax system or policy. Recognizing this study attempts to explore factors that determine citizens' tax compliance behavior in Gozamen district.

\section{Statements of the problem}

There are many studies on determinates of tax compliance behavior in sub -Sahara Africa including Ethiopia. The research finding revealed that taxpayers' perception about tax service quality and public governance quality significantly related to the compliance behavior. In addition, the effect of taxpayers' financial condition strengthened the capacity of the compliance model in predicting taxpayers' behavior better and significantly moderated the influences of tax system structure, moral reasoning and occupation (James O.2012).

It is also found that tax payer's voluntary compliance behavior with the tax system influenced by economical, institutional, social, individual and demographic variables (Niway, 2015).

An increase in the perception of individuals about the difficulty of evading taxes is found to increase the likelihood of tax compliant attitude in Kenya and South Africa. They also found that individuals who are more satisfied with public service provision are more likely to have a tax compliant attitude in all the four countries. However, frequent payment to non - state actors, e.g. to criminal gangs in exchange for protection, reduces individual's tax compliant attitude. Furthermore, those individuals who perceive that their ethnic group is treated unfairly are less likely to have a tax compliant attitude in Tanzania and South Africa (Merima etal,2014).

A study conducted in Dire Dawa city found that taxpayers' voluntary compliance behavior were determined by, tax fairness and equity, organizational strength of the tax authority, awareness level of the taxpayers, sociocultural factors, and provision of social services by the government( (Lemessa Tulu , 2007 ). However, evidence from the literature reviewed shows that, no homogeneity in the determinants of tax compliance behavior as stated in literature review part and in addition, to the knowledge of the researcher there were no study in similar topic in Gozamen district hence, the researcher is motivated to investigate factors which are determining tax compliance behavior in Gozamen district.

\section{Research Method}

The research approach is quantitative research design to investigate determinates of tax compliance behavior in Gozamen woreda and the type of research is descriptive research type.

This study used primary data collected from category "C" business income tax payers. The population reference of the study consists of 1, 352 category " $C$ " business income tax payers in Gozaman district. The study employed simple random sampling techniques and the source of the data is primary data collected from category $\mathrm{C}$ business income tax payer's individual in Gozaman district which can be taken as the sampling units. In order to determine the appropriate sample size, since the population finite and know population size the study used the following formula;

$$
n=\frac{\frac{N}{1+N(e)^{2}}(\text { Yeman, 1967). }}{1352} \approx
$$

$=\frac{1352}{1+1352(0.05)^{2}} \approx 318$. Where e is the marginal error (commonly use $\left.\mathrm{e}=5 \%\right), \mathrm{n}$ sample size and $\mathrm{N}$ population of the study.

In simplest way the dependent and independent variables which will be included in the model are the following: Dependent variable: compliance behavior of tax payers (COMP) i.e. 1 if the tax payer behavior in compliance and 0 , otherwise. It is convenient to divide compliance behavior into compliance and non compliance based on paying on time adopted from OECD, 2001.

Independent variables are:

Age of the business (age):- It is a continuous variable i.e year of stay of an individual in the business.

Religious status of the individual (relg):-It is a Categorical variable 0. Islam 1. Christian

Marital status of household heads (marts):- It is 1. Single 2. Married 3. Divorced 4. Widowed

Educational status of household head (eduhh):-It is measured as ordinal scale 0, for illiterate, 1 primary, 2 Secondary and 3 higher educations complete

Sex of a business owner (sex):-It is measured as categorical variable male 1 female 0

Tax knowelde (taxkno):-It is measured by proxy variable frequency of training obtained by tax payers in a year. Taxpayers' perceptions of tax penalties and sanctions (penal):- It is measured by 5 scale likert sacle Tax paying ability (incom):-It is a continues variable measured by amount of gross income earned within a year and it is continuous variable. 
Probability of tax audit (audit):-It is a dummy if, and Yes 1 and 0 other wise.

Perception of tax payers on government spending on infrastructure (govexp):- It can be taken as dummy variable labeled as Yes 1 other wise 0 .

Probability of detecting mistake by tax authority can be taken as dummy variable Yes 1 , otherwise 0 .

Referent group (refra):-Measured the influence of referent group in compliance behavior by 5 scale liker scale 0 for strongly agree, 1 for agree, 2 no opinion, 3 agree 4 , for strongly agree

Household family size (hhfsize):-number of people live in a household.

Experience on business activity (expbus):-The year of a person stay in the business activity which is continuous variable.

The model can be put as follows;

$\mathrm{Yi}=\beta_{\mathrm{o}}+\beta_{1} \mathrm{X}_{1}+\beta_{2} \mathrm{X}_{2+---++} \beta_{\mathrm{n}} \mathrm{X}_{\mathrm{n}}+\mathrm{Ui}$.

Where $\mathrm{Yi}$ is the dependent variable compliance behavior for business income tax payers individual $\mathrm{i}, \mathrm{Xi}$ is a vector of explanatory variables, $\beta \mathrm{i}$ is a vector of coefficients; $\beta_{\mathrm{o}}$ denotes unobserved tax compliance behavior and $\mathrm{Ui}$ is the error term. The probability of the business income tax payer individual has non -tax compliance behavior is given by;

$\mathrm{P}(\mathrm{Yi}=0)=\frac{\exp (\mathrm{Xi} \beta \mathrm{i})}{1+\exp (\mathrm{Xi} \beta \mathrm{i})}$

The business income tax payer individual has tax compliance behavior (1-P) is given by;

$\mathrm{P}(\mathrm{Yi}=1)=\frac{\exp (X i \beta i)}{1+\exp (X i \beta)}$

The average marginal effect of a given independent variable $\mathrm{Xi}$

$\frac{\partial P(Y i=1)}{\partial X i}=\frac{\exp (X i \beta i)}{1+\exp (X i \beta i)}$

The study employed both descriptive statistics, and inferential statistics methods of data analysis. The descriptive statistics was summarized using average, minimum, maximum, standard deviation, percentage, and it was also presented in the form of multipurpose table, bar graph and histo -graph. For inferential statistics, marginal effect of the logit model is used to show factors affecting tax compliance behavior. Data analysis was done with the help of STATA 14 software package.

\section{Discussion and Results}

In this part of this study the researcher would like to discuss the descriptive as well as inferential statistics clearly. The descriptive statistics will be analyzed mostly using percentage and to some extent by using, mean, minimum, maximum and standard deviation. Additionally, the inferential statistics will be analyzed with correlation.

\subsection{Descriptive Statistics}

From the total of 318 questioners distributed 100 percent of them filled properly and returned well hence, the analysis were made based on the data obtained from all the sampled category $\mathrm{C}$ business income tax payers in Gozamen woreda. The analysis were summarized as follows ;

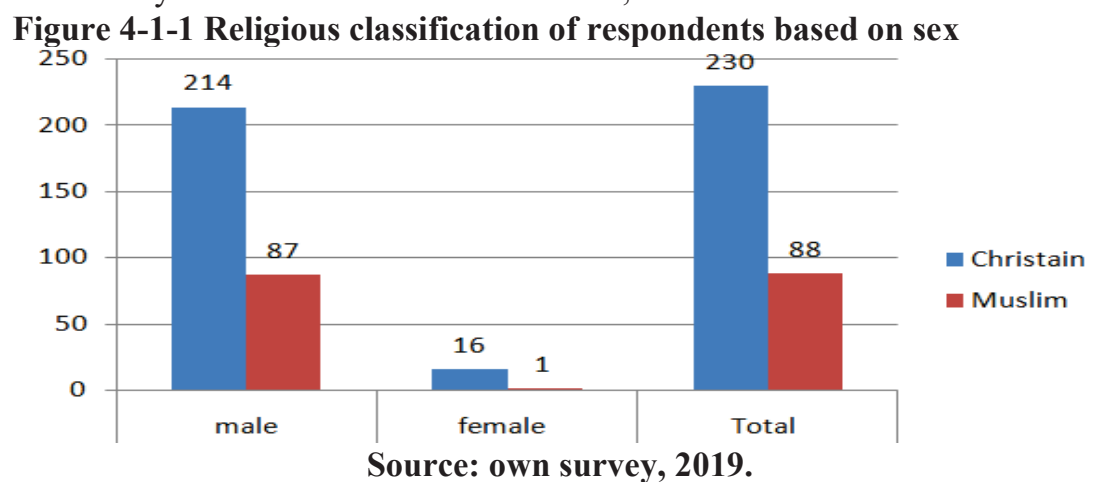

The above graph shows that from the total of 318 category $\mathrm{C}$ business income tax payers 88 of the respondents are followers of Muslim religion of this subtotal 87 of them were male and only 1 female and 230 of them follows Christian religion of this subtotal 214 were males and the remain 16 were females . 
Table: 4-1-1Classification of Tax compliance behavior of respondents by sex

\begin{tabular}{llll}
\hline Compliance behavior & \multicolumn{3}{c}{ Sex } \\
\cline { 2 - 4 } & Male & Female & Total \\
\cline { 2 - 4 } Non compliance & 98 & 31 & 129 \\
Compliance & 132 & 57 & 189 \\
Total & 230 & 88 & 318 \\
\hline
\end{tabular}

Source: own survey, 2019.

The above table shows that from the total of 318 sampled respondents 129 (98 male and 32 female) are non -compliance where as more than half (189) of this subtotal 132 are male and 57 are females are compliance category $\mathrm{C}$ business income tax payers.

Figure: 4-1-2Educational status of respondents

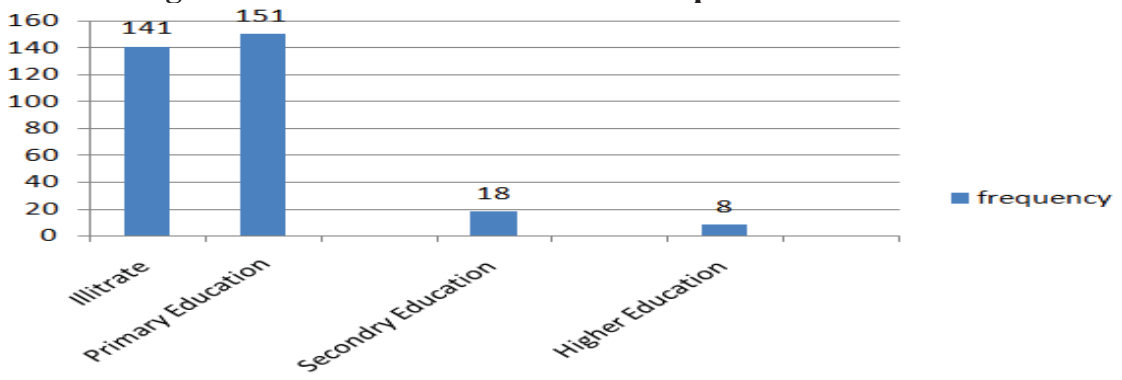

Source: own survey, 2019.

The above figure shows that from the total of 318 respondents 241(43.37\%), 151(44.34\%), 18(5.66\%),8 $(2.5 \%)$ of the respondents are illiterate, primary education ,secondary and higher education completes respectively

Figure: 4-1-3 marital status of the respondents

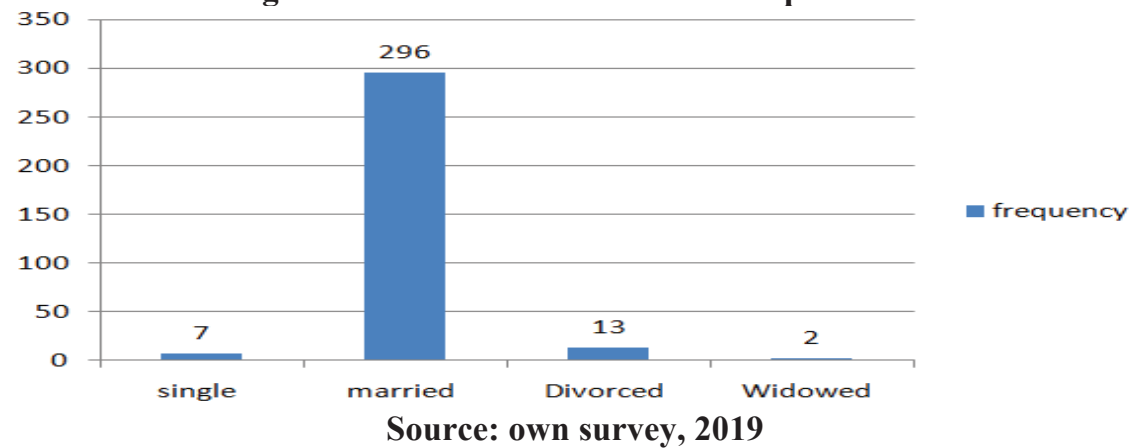

The above Figure shows that from the total of 318 respondents 7(2.2\%) single, 296(93.08\%) married, 13(4.08) divorced and remain 2(0.63\%) of the respondents are widowed.

Table:4-1-2 Descriptive statistes for continoius varaibles

\begin{tabular}{lccccc}
\hline Variable & Obs & Mean & Std. Dev. & Min & Max \\
\hline Income & 318 & 287919.1 & 112418.9 & 78090 & 455400 \\
Age & 318 & 42.8805 & 10.33896 & 19 & 83 \\
Households family size & 318 & 4.54717 & 1.911935 & 1 & 12 \\
Year of Experience on the business & 318 & 24.71384 & 11.6222 & 0 & 70 \\
\hline
\end{tabular}

Source: own survey, 2019.

From the above table the mean taxable income of category $\mathrm{C}$ business income tax payers is birr 287919.10 per annum. It is also showed the maximum and the minimum amount of taxable income of category $\mathrm{C}$ business income tax payers is birr 78,090 and birr455,400 respectively with standard deviation of taxable income birr $112,418.90$ in Gozamen woreda .

From the above table the mean age of category $\mathrm{C}$ business income tax payers is a round 42 years. It is also showed the maximum and the minimum age of category $\mathrm{C}$ business income tax payers is 19 and 83 respectively with standard deviation of 10.33 years in Gozamen woreda .

From the above table the mean household family size of category $\mathrm{C}$ business income tax payers is a round between 4 and 5 per household. It is also showed the maximum and the minimum family size of category $\mathrm{C}$ business income tax payers is 1 and 12 respectively with standard deviation of around 10 years in Gozamen 
woreda.

It can also be observed from the above table the mean year of experience stay on the business of category $\mathrm{C}$ business income tax payers is 24.71. It is also showed the maximum and the minimum year of experience stay on the business category $\mathrm{C}$ business income tax payers is 0and 70 respectively with standard deviation of 11.62 years stay on the business in Gozamen woreda .

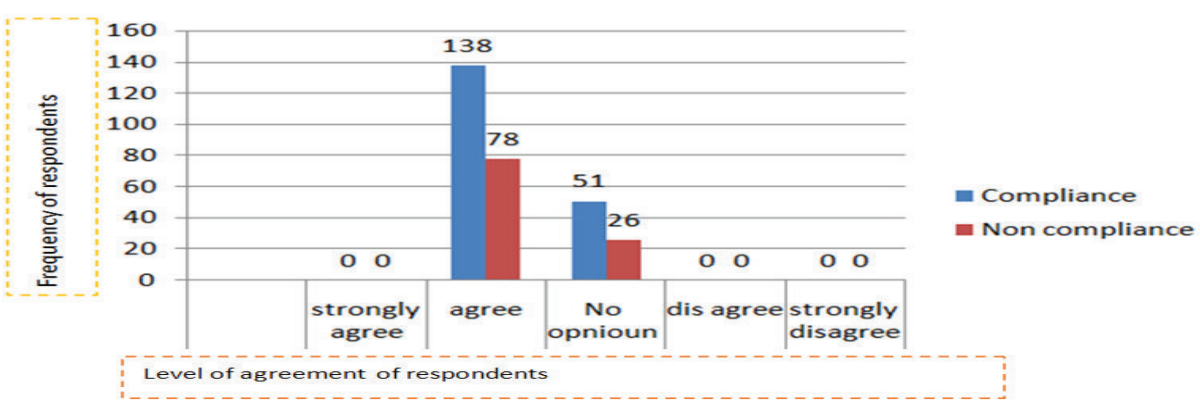

Source: own survey, 2019

The above table shows that large number of respondents (138) of the sampled respondents agreed that is believed to make tax payers compliance but no respondents strongly dis agree these statements. This means that referent group makes tax payers to have compliance behavior. This shows that faire treatment (vertical or horizontal equity) of taxation insure tax compliance behavior among category $\mathrm{C}$ business income tax payers.

Figure: 4-1-5 Tax compliance behavior and legal sanction and penalty status of respondents

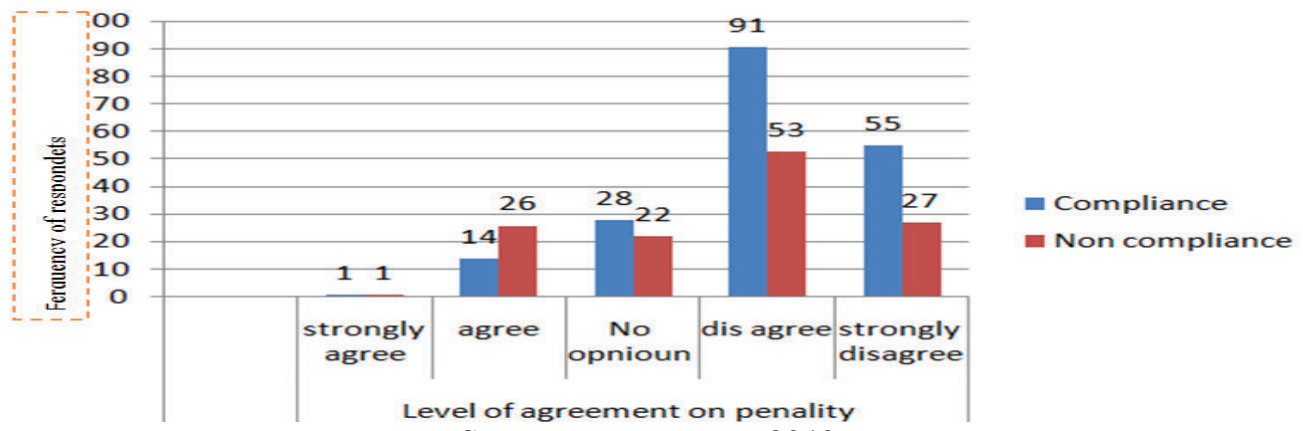

Source: own survey, 2019

The above table shows that 91 of the sampled tax compliance respondents and 53 of non compliance disagreed that fear of penalty made by tax authority will make tax payers to have compliance behavior and 24 compliance behaviors and 26 non compliance behaviors agreed that penalty will make tax compliance behavior.

\subsection{Inferential statistics Result}

In order to investigate the determinates of tax compliance behavior of category $\mathrm{C}$ business income tax payers in Gozamen woreda the estimated binary logit marginal effect result will be summarized as follows . But before, accepting the estimated model result all important relevant tests were carried out and the test results are shown that no diagnostic problems in this study .

Table 3-2-1: The estimated marginal effect Result of the logit model

\begin{tabular}{llll}
\hline Variable & $\mathbf{d y} / \mathbf{d x}$ & $\mathbf{Z}$ & $\mathbf{P}>\mathbf{Z}$ \\
\hline Sex & 0.039335 & 0.55 & 0.583 \\
HHfsize & 0.0136795 & 0.77 & 0.456 \\
Marts & 0.1120585 & 1.01 & 0.315 \\
Relg & -0.1813757 & -1.48 & 0.138 \\
Taxknow & 0.0845357 & 1.12 & 0.263 \\
Age & 0.0044214 & 1.00 & 0.315 \\
Govexp & 0.1395042 & 1.55 & 0.120 \\
sefra* & -0.2137977 & -3.79 & 0.000 \\
Income & $-2.28 \mathrm{e}-08$ & -0.08 & 0.932 \\
expbus* & -0.139708 & -3.60 & 0.000 \\
Penal* & 0.1095942 & 3.37 & 0.001 \\
Audit & -0.0298859 & -0.96 & 0.340 \\
Edu & -0.0336388 & -0.73 & 0.464 \\
\hline
\end{tabular}

*means significance at 1 percent level of significant.

Source: own survey, 2019. 
The interpretation of the model results will be as follows;

1. Referent group:-Keeping all other factors constant, if the influence of referent group rise by one unit, the average marginal effect shows that, the probability of being tax compliance decreases on average by 0.213 percent and statistically significant at 1percent. This finding confirmend to the finding (Niway Ayalew,etal ,2015) which states that the influence of referral group were determinant factors that influence voluntary compliance behavior of tax payers.

2. Year of Experience on the business:-Keeping all other factors constant, if year of experience on business increased by one year, the average marginal effect shows that, the probability of being tax compliance decreases on average by 0.0139 percent and statistically significant at 1 percent. This is explained as the year on business increase, business man clearly now how avoid tax, how to evade tax and under state income tax declare to Gozamen woreda revenue office.

3. Legal sanction and penalty: Keeping all other factors constant, if the revenue office penalizes tax non complaints, the average marginal effect shows that, the probability of being tax compliance increased on average by 0.1095 percent and statistically significant at 1 percent. This implies that if revenue office enfocre laws and regulation properly and penalize non compliants, due to the frear of the legal sanction and penality tax payers , and leraning from other and become compliant.

\section{Conclusions and Recommendation}

The research findings reveled that tax compliance behavior of category $\mathrm{C}$ business income tax payers of the sampled tax payers is significantly influenced by experience on business, legal sectional and penalty and the influence of referral groups of tax payers. Based on the study findings of this study the following policy implications are recommended by the searcher.

- Gozamen woreda Revenue office should create awareness in reducing the influence of referent group on tax payer to raise tax compliance behavior of category $\mathrm{C}$ business income tax payers.

- Gozamen woreda Revenue office should create awareness in reducing non compliance behavior of experienced business man to rise tax compliance behavior of category $\mathrm{C}$ business income tax payers and then ;

- Gozamen woreda Revenue office should impose legal sanction and penality as well as enfoecing tax laws and regulation to ris tax complaince behaviour of category $\mathrm{C}$ business income tax payers.

\section{REFERENCE}

Adams, T.S. (1921). Fundamental problems of Federal Income tax Taxation. Quarterly Journal of Economics 35(4), 527-557.

Allingham, M.G. and Sandmo, A.(1972). "Income Tax Evasion: A Theoretical Analysis". Journal of Public Economics.

Andreoni, J. and et al (1998). Tax Compliance. Journal of Economic Literature,Vol. 36, No.2. American Economic Association .

Bhatia, H.L.(1976). Public Finance, $19^{\text {th }}$ edition. New Delhi, India: Vikas Publishing House Pvt Ltd.

Beesoon. D, Hemavadi P Soondram, and Jugurnath. B, (2016).Assessing the Determinants of Income Tax Compliance in Mauritius: A Study of Individual Taxpayers. Proceedings of the Fifth Asia-Pacific Conference on Global Business, Economics, Finance and Social Sciences pp 21-23.

Bird, R. M. and Oldman, O. (1967). Readings on Taxation in Developing Countries, Revised. Edition. Baltimore, USA: The John Hopkins Press.

Brooks, N. (2001). Key Issues in Income Tax: Challenges of tax administration and compliance. Asian Development Bank Tax Conference paper .

Due,J.F. and Friedlaender, A.F. (1981). Government Finance: economics of the Public Sector 7th ed. Illinois, USA: Richard D. IRWIN, INC. Eckstein, Otto. (1979). Public Finance $4^{\text {th }}$ edition. Englewood Cliffs, USA: Prentice- Hall, INC.

Edlund, J. (2003). “Attitude towards Taxation: Ignorant and Incoherent?" Scandinavian Political Studies, Vol.26, No.2. Nordic Political Science Association .

Federal Inland Revenue Authority (2000). "Components of Tax Administration". Tax, Vol.1, no 3, FIRA, Addis Ababa.

Fjeldstad, O. (2004). To Pay or Not to Pay? Citizens' Views on taxation in local authorities in Tanzania. Working paper, Bergen, Norway: Chr.Michelsen Institute.

Fjeldstad,O. and Ranker, L. (2003). "Taxation and Tax Reforms in Developing Countries: Illustration from subSaharan Africa”. Bergen, Norway: Chr.Michelsen Institute.

James O. Alabede (2012). "An Investigation of Factors Influencing Taxpayers' Compliance Behavior": Evidence from Nigeria. MA un published thesis.

James, S. and Nobes, C. (2000). The Economics of Taxation: Principles, Policy and Practice $7^{\text {th }}$ edition. 


\section{Prentice-Hall.}

James, S. et al (2003). "Tax Compliance Policy: An International Comparison and New Evidence on Normative Appeals and Auditing": Unpublished manuscript.

Lemessa Tulu. (2007). “A research project on Determinants of taxpayers' Voluntary Compliance with taxation the case study of Dire Dawa city". MA Thesis, Addis Abeba University.

Lemessa, B. (2005). Federal Income Tax Administration in Ethiopia: The Case of Employment and Business Income Taxes, Unpublished Msc. Thesis, AAU.

Merima Ali, Odd - Helge Fjeldstad and Ingrid Hoem Sjursen (2016). "Factors affecting tax compliant attitude in Africa": Evidence from Kenya, Tanzania, Uganda and South Africa Chr.Michelsen Institute Bergen, Norway.

Niway Ayalew Adimassu, and Wondwossen Jerene (2015). "Determinants of Voluntary Tax Compliance Behavior in Self Assessment System": Evidence from SNNPRS, Ethiopia. International Journal of Science and Research (IJSR) ISSN (Online).

The Committee of Fiscal Affairs Forum on Strategic Management OECD (2001).Compliance Measurement practice note. Tax guidance Series .Centre for Tax Policy and Administration. 